\title{
Hepatitis B Virus and Hepatitis C Virus Seroprevalence in Hemodialysis Patients in Eskișehir Yunus Emre State Hospital
}

\author{
Eskișehir Yunus Emre Devlet Hastanesi Hemodiyaliz Hastalarında Hepatit B Virüsü, Hepatit C \\ Virüsü Seroprevalansı
}

\author{
Pınar KORKMAZ1, Figen ÇAĞLAN ÇEVIK1, Nevil AYKIN1, Rüya MUTLUAY2, \\ 1 Yunus Emre State Hospital, Clinics of Infectious Diseases and Clinical Microbiology, Eskişehir, Turkey \\ 2 Yunus Emre State Hospital, Clinic of Nephrology, Eskişehir, Turkey \\ 3 Yunus Emre State Hospital, Infection Control Committee Nurse, Eskişehir, Turkey
} Hakkı Mustafa GÜLDÜREN1, Yeşim ALPAY1, Zühre DOĞRU YAŞAR3, Melahat UĞUR3

\section{Dear Editor,}

In chronic renal failure (CRF), infections are important causes of morbidity and mortality. Impaired immune system, frequent blood transfusion because of anemia, vascular intervention for hemodialysis, and exposure to infected patient or equipment are the factors that increase the risk of viral hepatitis infection in hemodialysis (HD) patients $(1,2)$. In a study evaluating viral hepatitis epidemiology in kidney disease (including patients who were on regular hemodialysis, and peritoneum dialysis and renal transplant recipients) performed in in 2010, it has been reported that the prevalence of HBsAg positivity was $3.9 \%$ and anti-HCV positivity rate was $8.5 \%(3,4)$. In this study, we aimed to determine the seroprevalence of $\mathrm{HBsAg}$ and hepatitis $\mathrm{C}$ virus $(\mathrm{HCV})$ as well as antibody response against hepatitis $B$ vaccination in $\mathrm{HD}$ patients due to CRF in our hospital.

HBsAg, anti-HBs and anti-HCV parameters of 64 patients, who underwent HD in 2013, were retrospectively evaluated from patient files. Serum samples were analyzed by a chemiluminescent immunoassay (ELISA, Liaison, Diasorin, Italy). Statistical analyses were performed by SPSS version 19 (Statistical Package for Social Sciences) package program. Twenty-nine (45.3\%) patients were male, 35 (54.7\%) were female. The mean age was $59.89 \pm 13.85$ years. Duration of HD ranged between 12 and 252 months with a mean duration of $83.47 \pm 73.25$ months. None of the patients was positive for HBsAg. Anti-HBs was positive in 56 (87.5\%) patients and in 24 were positive for anti-HBs despite the absence of history of vaccination against hepatitis B. Fifteen patients (23.4\%) were positive for anti-HCV. The anti-HCV positivity was confirmed by repeat testing in all anti-HCV positive patients. Anti-HBs titer was lower than $10 \mathrm{mlU} / \mathrm{mL}$ in $4(11.1 \%)$ of 36 patients who have completed hepatitis B vaccination schedule. Four patients had not hepatitis vaccination despite being recommended by their physicians.

In a study from Turkey, the prevalence of HBsAg positivity in HD patients was $5.5 \%$ and anti-HCV positivity was $16 \%$ (5). In this study, HBsAg positivity was not detected in our HD patients and anti-HCV positivity rate was found to be $23.4 \%$. High anti-HCV positivity rates in our HD patients were attributed to the limited number of patients, the majority (86\%) of patients' being at the age of 50 years and over, longer duration of dialysis, and the patients history of undergoing dialysis in more than one center.

Impaired immune response against hepatitis B vaccine is a problem in patients with end-stage renal failure including dialysis patients. In a study from Turkey, the rate of anti-HBs negativity following 3 doses of vaccination against hepatitis $B$ has been reported to be $10.4 \%$ (6). Our rate of anti-HBs negativity after vaccination against hepatitis B was $11.1 \%$. We assume that this study will contribute to the epidemiological data on seroprevalence of HBV and HCV among HD patients in the Eskişehir Province.

Anahtar kelimeler: Hemodiyaliz, hepatit B, hepatit C Key words: Hemodialysis, hepatitis B, hepatitis C 


\section{References}

1. Telaku S, Fejza H, Elezi Y, Bicaj T. Hepatitis B and C in dialysis units in Kosova. Virology J. 2009; 6: 72.

2. Zacks SL, Fried MW. Hepatitis $B$ and $C$ and renal failure. Infect Dis Clin North Am. 2001; 15: 877-899.

3. Serdengeçti K, Süleymanlar G, Altıparmak MR, Seyahi N. Türkiye'de Nefroloji-Diyaliz ve Transplantasyon. Türk Nefroloji Derneği Yayınları, Registry of the Nephrology, dialysis and 8transplantation in Turkey, Registry 2010.
4. Tosun S. Viral Hepatitlerin Ülkemizdeki Değişen Epidemiyolojisi. ANKEM Derg. 2013; 27(Ek 2): 128-134.

5. Çopur Çiçek A, Şahin OZ, Topaloğlu MK, Kazancı AT, Yenilmez $\mathrm{IH}$, Şahin K, ve ark. Rize Illinde Hemodiyaliz Hastalarında HBsAg, Anti-HBs ve Anti-HCV Seroprevalansı. Vir Hep Derg. 2013; 19(1): 15-8.

6. Temiz H, Kaya Ş, Berekatoğlu N, Temiz S, Danış R. Hemodiyaliz Hastalarında HBV, HCV ve HIV Seroprevalansı ve Hepatit B Aşılaması ile Oluşan Antikor Cevabının Değerlendirilmesi. Vir Hep Derg. 2013;19(3): 140-143. 